\title{
Pengaruh Hemolisis Terhadap Nilai Trombosit Dengan Menggunakan Metode Direct Counting
}

\author{
Nurmalita Putri Nugrahena $^{1}$, Tantri Analisawati Sudarsono ${ }^{2}$, Linda Wijayanti ${ }^{3}$ \\ ${ }^{123}$ Program Studi Teknologi Laboratorium Medik D4, Fakultas Ilmu Kesehatan, Universitas Muhammadiyah Purwokerto \\ ${ }^{4}$ Rumah Sakit Umum Daerah Banyumas, Indonesia
}

\begin{tabular}{|c|c|}
\hline Article Info & ABSTRACT \\
\hline Article history: & $\begin{array}{l}\text { Hemolysis is the breakdown of red blood cells and the release of } \\
\text { hemogiobin into the plasma. It can ocur in vitro and in vivo. The }\end{array}$ \\
\hline Received Feb $26^{\text {th }} 2021$ & hemolyzed specimen can affect the results of laboratory tests which \\
\hline Revised Aug 30 2021 & can lead to misdiagnosis, therapy and prevention. The purpose of this \\
\hline Accepted Sep $26^{\text {th }} 2021$ & study was to determine the effect of hemolysis on platelet values using \\
\hline Keyword: & $\begin{array}{l}\text { values between non-hemolyzed specimen and hemolyzed specimen in } \\
\text { vitro. This research was conducted expernimentally in July } 2020 \text { at the }\end{array}$ \\
\hline Blood & Clinical Pathology Laboratory, Faculty of Medicine, Universitas \\
\hline Platelets & Muhammadiyah Purwokerto. The sampling technique was caried out \\
\hline Hemolysis & by purposive sampling in which 14 specimens were involved. \\
\hline In vitro & $\begin{array}{l}\text { Afterwards, the platelet value was determined using the direct } \\
\text { counting method. Based on the results of data analysis, it demonstrated } \\
\text { a significance value of } 0.000(\mathrm{p} 0.05) \text {. Therefore, it can be concluded } \\
\text { that there is a significant difference of platelet values between non- } \\
\text { hemolyzed specimen and hemolyzed specimen. }\end{array}$ \\
\hline
\end{tabular}

\begin{abstract}
ABSTRAK
Hemolisis yaitu pecahnya sel darah merah dan keluarnya hemoglobin ke plasma. Hemolisis dapat terjadi secara in vitro dan in vivo. Sampel yang hemolisis dapat mempengaruhi hasil pemeriksaan laboratorium yang dapat menyebabkan kesalahan diagnosis, terapi dan prevensi. Tujuan penelitian ini adalah untuk mengetahui pengaruh hemolisis terhadap nilai trombosit dengan menggunakan metode direct counting serta mengetahui perbedaan nilai trombosit dari sampel darah yang tidak lisis dan dilisiskan secara in vitro. Penelitian ini dilakukan secara eksperimental pada bulan Juli 2020 di Laboratorium Patologi Klinik Fakultas Kedokteran Universitas Muhammadiyah Purwokerto. Teknik pengambilan sampel dilakukan secara purposive sampling sebanyak 14 sampel. Perhitungan nilai trombosit dilakukan menggunakan menggunakan metode direct counting. Berdasarkan hasil analisis data menunjukan nilai signifikansi yaitu $0,000(\mathrm{p}<0,05)$ maka terdapat perbedaan yang signifikan pada nilai trombosit dengan menggunakan sampel yang tidak lisis dan sampel hemolisis.
\end{abstract}

Kata Kunci: Trombosit, Darah, Hemolisis, In vitro.

\section{Pendahuluan}

Terdapat beberapa jenis pemeriksaan darah yang dapat dilakukan di laboratorium klinik. Pemeriksaan yang umumnya dilakukan yaitu hitung darah lengkap (HDL) atau complete blood count (CBC), Pemeriksaan hemoglobin, pemeriksaan hematokrit, dan pemeriksaan darah lainnya. Pemeriksaan darah lengkap mampu mendeteksi berbagai macam gangguan di dalam darah seperti anemia, infeksi dan leukimia. Salah satu 
pemeriksaan yang termasuk dalam pemeriksaan darah lengkap adalah pemeriksaan hitung jumlah darah. Pemeriksaan hitung jumlah darah dilakukan dengan menghitung jumlah komponen darah. Beberapa komponen darah yang dihitung yaitu eritrosit, leukosit, hemoglobin, hematokrit, dan trombosit (Sallika, 2010). Hasil pemeriksaan dapat dipengaruhi oleh beberapa faktor, salah satunya adalah hemolisis. Kesalahan dalam pemeriksaan laboratorium dapat menyebabkan kesalahan diagnosis, terapi dan prevensi.

Hemolisis merupakan gangguan yang terjadi pada membran eritrosit sehingga terjadi pelepasan hemoglobin (Riswanto, 2013). Hemolisis ditandai dengan kondisi serum yang berwarna kemerahan karena lepasnya hemoglobin dari eritrosit yang rusak. Hemolisis dapat terjadi secara in vitro dan in vivo. Hemolisis secara in vivo dapat disebabkan oleh adanya infeksi, zat beracun, reaksi transfusi dan anemia hemolitik (Elrouf, 2013) Walaupun hemolisis dapat terjadi secara in vivo, hemolisis secara in vitro dalam pra analitik menjadi salah satu masalah utama pada laboratorium klinik (Unlu, 2018). Penelitian ini bertujuan untuk mengetahui apakah ada perbedaan nilai trombosit pada sampel tidak lisis dan sampel hemolisis dengan menggunakan metode direct counting.

\section{Metode Penelitian}

Penelitian ini dilakukan secara eksperimental dengan rancangan pre test and post test only control grup design yang terdiri atas dua kelompok. Kelompok pertama sebagai kontrol positif dengan perlakuan sampel darah yang tidak dilisiskan. Kelompok kedua dengan perlakuan sampel darah dilisiskan dengan cara memberikan tekanan dan tidak melepas jarum pada saat dikeluarkan dari syringe, setelah sampel darah masuk ke dalam tabung dilakukan homogenisasi atau pengocokan kemudian dihitung nilai trombositnya. Darah yang diambil sebanyak $3 \mathrm{ml}$, darah dimasukkan ke dalam tabung antikoagulan EDTA kontrol dan perlakuan masingmasing sebanyak $1,5 \mathrm{ml}$ kemudian dilakukan perhitungan trombosit menggunakan metode direct counting dengan bilik hitung. Larutan pengencer yang digunakan adalah larutan rees ecker yang berfungsi melisiskan leukosit sehingga tidak mengganggu saat perhitungan trombosit. Sampel dalam penelitian ini adalah sebanyak 14 mahasiswa Program Studi Teknologi Laboratorium Medik D4 angkatan 2016 periode 2019/2020

Variabel bebas yaitu sampel hemolisis dan variabel terikat yaitu nilai trombosit. Analisis hasil penelitian dianalisis homogenitas dan normalitasnya dengan menggunakan uji normalitas. Dilakukan uji T berpasangan untuk mengetahui pengaruh hemolisis pada sampel yang tidak lisis dan hemolisis.

\section{Hasil Penelitian dan Pembahasan}

Distribusi frekuensi jenis kelamin responden pada penelitian dapat dilihat pada Tabel 1.

Tabel 1. Distribusi Jenis Kelamin Responden

\begin{tabular}{ccc}
\hline Jenis Kelamin & Jumlah & Pesentase \\
\hline Wanita & 12 & 85,7 \\
Pria & 2 & 14,3 \\
Total & 14 & 100,0 \\
\hline
\end{tabular}

Berdasarkan Tabel 1, diketahui bahwa presentase responden berjenis kelamin wanita paling tinggi $(85,7 \%)$ sedangkan presentase responden berjenis kelamin pria $(14,3 \%)$. 
Tabel 2. Distribusi Usia Responden

\begin{tabular}{ccccccc}
\hline Usia & Jumlah & Presentase & Mean & Median & SD & Minimal-Maksimal \\
\hline 20 & 1 & 7,1 & & & & \\
21 & 6 & 42,9 & & & & \\
22 & 6 & 42,9 & 21,50 & 21,50 & 0,760 & \\
23 & 1 & 7,1 & & & \\
Total & 14 & 100 & & & \\
\hline
\end{tabular}

Berdasarkan Tabel 2, diketahui rerata usia responden yaitu 21,50 tahun, median 21,50 tahun, dan standar deviation 0,760 tahun dengan umur paling muda 20 tahun dan usia paling tua 23 tahun.

Pengaruh hemolisis terhadap nilai trombosit pada sampel tidak lisis dan sampel hemolisis dapat dilihat pada Tabel 3 .

Tabel 3. Hasil Analisis Uji T Berpasangan Nilai Trombosit pada Sampel Tidak Lisis dan Sampel Hemolisis

\begin{tabular}{lccccc}
\hline \multicolumn{1}{c}{ Variabel } & N & Mean & SD & SE & P Value \\
\hline Nilai Trombosit & & & & & \\
Sampel Tidak Lisis & 14 & $262.857,14$ & 76904,393 & 20553,564 &, 000 \\
Sampel Hemolisis & 14 & $388.571,43$ & 104429,376 & 27909,925 & \\
\hline
\end{tabular}

Berdasarkan Tabel 3, yang dianalisis menggunakan uji $\mathrm{T}$ berpasangan, rerata rerata nilai trombosit pada sampel tidak lisis adalah 262.857,14 (SD 76904,393) sel/ $\mu$ l darah. Pada sampel hemolisis didapatkan rerata nilai trombosit 388.571,43 (SD 104429,376) sel/ $\mu$ l darah. Terlihat nilai mean perbedaan antara

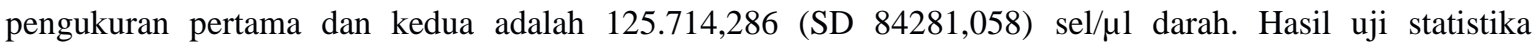
menunjukan nilai signifikansi yaitu sebesar 0,000 ( $\mathrm{p}<0,05)$ maka terdapat perbedaan jumlah trombosit yang signifikan antara sampel tidak lisis dan sampel hemolisis.

Serum adalah bagian darah yang tersisa setelah darah membeku (Gandasoebrata, 2013). Serum diperoleh dengan cara darah dibekukan pada suhu kamar selama 20-30 menit dan diputar dengan kecepatan 3000 rpm selama 5-15 menit. Cairan serum akan terbentuk dan terpisah dari sel-sel darah merah. Serum yang memenuhi syarat harus tidak terlihat merah dan keruh (Kemenkes, 2004). Serum normal memiliki warna kekuning-kuningan dan mempunyai sifat antigenik.

Serum yang berwarna keruh mengacu pada kekeruhan dari kadar lemak disebut serum lipemik (Ramali, 2005). Lipemik merupakan akumulasi partikel lipoprotein yang berlebih dalam darah sehingga darah menjadi keruh berwarna putih susu. Penyebab terjadinya serum lipemik adalah adanya partikel besar lipoprotein yaitu chylomicrons. Partikel lipoprotein seperti Very Low Density Lipoprotrein (VLDL), Low Density Lipoprotein (LDL), High Density Lipoprotein (HDL) dan trigliserida juga dapat menyebabkan kekeruhan sampel tetapi bukan merupakan penyebab utama kekeruhan pada serum lipemik (Sacher dan 
McPherson, 2004). Serum dengan kadar trigliserida dan kolesterol lebih dari normal yaitu lebih dari 200 $\mathrm{mg} / \mathrm{L}$ atau 2,26 mmol/L dapat beresiko menimbulkan kekeruhan pada sampel (Lee, 2009).

Serum lipemik dapat menyebabkan hasil pemeriksaan tidak akurat, pada pemeriksaan hitung jumlah trombosit serum lipemik dapat hasil pemeriksaan menjadi tinggi. Trombositosis dapat terjadi secara primer maupun sekunder. Adanya penyakit dasar mengarahkan pada terjadinya trombositosis reaktif. Trombositosis reaktif terjadi karena produksi berlebih dari sitokin proinflamasi seperti IL-1, IL-6, dan IL-11 yang muncul pada inflamasi kronik, infektif, dan keganasan. Lipid berperan pada sistem metabolik dan juga inflamasi. Kelainan metabolik akibat multifaktor juga memicu terjadinya proses inflamasi, termasuk hiperlipidemia yang kemudian akan melepaskan sitokin inflamasi yang memicu trombopoiesis sehingga terjadi trombositosis (Munawirah, 2019).

Sampel ikterik merupakan serum yang berwarna kuning coklat akibat adanya hiperbilirubinemia (peningkatan bilirubin dalam darah). Peningkatan kadar bilirubin dapat terjadi akibat ikterik obstruktif, karena neoplasma empedu, hepatitis, sirosis hati, metastasis hati, penyakit Wilson. Peningkatan kadar bilirubin dapat terjadi akibat penggunaan obat, misalnya antibiotik (amfoterisin B, klindamisin, eritrimisin, gentamisin, linkomisin. Oksalisin, tetrasiklin). Serum ikterik dapat menyebabkan hasil pemeriksaan tidak akurat, pada pemeriksaan hitung jumlah trombosit serum ikterik dapat hasil pemeriksaan menjadi rendah. Serum ikterik sering ditemukan pada pasien yang mempunyai masalah pada hepar. Misalnya pada pasien yang mengalami sirosis hati/penyakit hati seperti Hepatitis B. Adanya kerusakan pada hepar dapat mempengaruhi produksi hormon trombopoetin. Pasien sirosis hati dapat ditemukan trombositopenia. Hal ini terjadi karena adanya peningkatan sekuestrasi trombosit di dalam limpa akibat spenomegali, maupun karena menurunnya produksi trombopoetin di hati (Paraditha, 2016).

Serum hemolisis adalah serum yang berwarna kemerahan yang disebabkan karena lepasnya hemoglobin dari eritrosit yang rusak (Ghaedi, 2016). Hemolisis terlihat sebagai warna kemerahan pada serum atau plasma (Lippi, 2006). Hemolisis secara in vitro dapat disebabkan oleh penggunaan jarum yang terlalu kecil, pengambilan darah menggunakan spuit yang tidak lancar karena pembuluh darah tidak tertusuk sempurna.

Berdasarkan hasil penelitian nilai trombosit pada sampel darah yang tidak lisis secara keseluruh dalam keadaan normal yaitu sebesar 140.000-450.000 sel/ $\mu$ l darah. Nilai trombosit terendah adalah $160.000 \mathrm{sel} / \mu \mathrm{l}$ darah dan tertinggi sebesar $420.000 \mathrm{sel} / \mu 1$ darah. Setalah dilakukan pengolahan data didapatkan nilai rerata trombosit pada sampel tidak lisis sebesar 262.857,14 (SD 76904,393) sel/ $\mu 1$ darah. Sedangkan pada sampel hemolisis nilai trombosit secara keseluruhan lebih tinggi dibandingkan dengan sampel yang tidak lisis. Nilai trombosit terendah adalah $190.000 \mathrm{sel} / \mu \mathrm{l}$ darah dan tertinggi sebesar $550.000 \mathrm{sel} / / \mu \mathrm{l}$ darah. Rerata nilai trombosit pada sampel hemolisis sebesar adalah sebesar 388.571,43 (SD 104429,376) sel/ $\mu$ l darah.

Hasil penelitian menunjukan bahwa pemeriksaan nilai trombosit pada sampel yang hemolisis mengalami peningkatan nilai trombosit dibandingkan dengan sampel yang tidak lisis. Dari 14 sampel, $100 \%$ nilai trombosit pada sampel hemolisis lebih tinggi dari pada nilai trombosit pada sampel yang tidak lisis. Hasil analisis statistik dari Uji T Berpasangan menunjukan adanya perbedaan yang signifikan $\mathrm{p}$ value $0,000(\mathrm{p}<$ $0,05)$ terhadap nilai trombosit. 
Keadaan nilai trombosit lebih dari batas atas nilai normal yaitu lebih dari $450.000 \mathrm{sel} / \mu \mathrm{l}$ darah disebut dengan trombositosis. Biasanya terjadi saat keadaan infeksi, stress, ovulasi, inflamasi dan keganasan. Sedangkan penurunan jumlah trombosit kurang dari batas nilai normal yaitu kurang dari $140.000 \mathrm{sel} / \mu \mathrm{l}$ darah.disebut trombositopenia. Trombositopenia dapat disebabkan oleh produksi trombosit yang berkurang, dan kelainan distribusi atau destruksi yang meningkat (Kosasih, 2008).

Trombositopenia juga dijumpai pada penyakit Immune Thrombocytopenic Purpura atau ITP. Penyakit ITP adalah penyakit autoimun yang disebabkan adanya destruksi trombosit normal akibat adanya antibodi (antibody-mediated destruction of platelets) dan gangguan produksi megakariosit (Sari, 2018). Sampel hemolisis sering terjadi di lapangan, sehingga sebaiknya jika ditemukan sampel yang hemolisis maka perlu dilakukan pengambilan darah ulang. Sampel yang hemolisis sebaiknya tidak digunakan untuk pemeriksaan, karena terbukti mempengaruhi hasil pemeriksaan nilai trombosit.

\section{Kesimpulan}

Rerata nilai trombosit pada pemeriksaan jumlah trombosit dengan sampel yang tidak lisis sebesar 262857,14 (SD 76904,393) sel/ul darah. Rerata nilai trombosit pada pemeriksaan jumlah trombosit dengan sampel

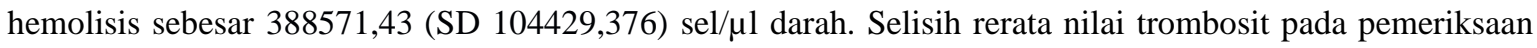
jumlah trombosit pada sampel tidak lisis dan lisis sebesar 125714,286 dengan $\mathrm{p}$ value $0,000(\mathrm{p}<0,05)$. Terdapat pengaruh hemolisis terhadap hasil pemeriksaan jumlah trombosit.

\section{Daftar Pustaka}

Departemen Kesehatan RI. 2004. Keputusan Menteri Kesehatan Republik Indonesia Nomor 1197/Menkes/SK/X/2004. tentang Standar Pelayanan Farmasi di Rumah Sakit. Jakarta.

Elrouf, M.B., Abdul, M., Amanullah, G.S.Z. 2013. Interference of Hemolysis in the Estimation of Plasma Aspartate Aminotransferase, Potassium and Phosphate. Journal Invest Biochemistry. 1(1): 12-16

Gandasoebrata, R. 2013. Penuntun Laboratorium Klinis. Dian Rakyat. Jakarta.

Ghaedi, M. dan Joe, M. E. 2016. Liquichek Serum Indices. http://www.qcnet.com/serumindices/pdf/Q1652.pdf. Diakses pada tanggal 19 April 2020.

Kosasih, E.N dan A.S Kosasih. 2008. Tafsiran Hasil pemeriksaan Laboratorium Klinik edisi Kedua. Karisma Publishing Group. Tangerang.

Lippi, Giuseppe,dkk. 2006. Influence of hemolysis on routine clinical chemistry testing. Journal Clin Chem Med. 4(3):311-316

Lee, M. 2009. Basic Skill in Interpreting Laboratory Data Fourth Edition. American Society of Health-System Pharmacistis, Inc. Maryland

Munawirah, Andi. 2019. Interferensi sampel lipemik pada bayi dengan lipemia retinalis dikarenakan primary mixed hyperlipidemia: laporan kasus. Intisari Sains Medis, 10(2): 413-419

Paraditha, Vella. 2016. Gambaran Kadar Trombosit, Besar Limpa dan Kadar Albumin Serum pada Pasien Sirosis Hati dengan Varises Esofagus. Jurnal Kesehatan Andalas, 5(3) : 680-686.

Ramali, A dan Pamoentjak. 2005. Kamus Kedokteran. Djambaran. Jakarta 
Riswanto. 2013. Pemeriksaan Laboratorium Hematologi. Alfamedia. Yogyakarta.

Sacher, R. A., and McPherson, R. A. 2004. Tinjauan Klinis Hasil Pemeriksaan Laboratorium. EGC. Jakarta. Sallika. 2010. Serba-Serbi Kesehatan Perempuan Apa Yang Perlu Kamu Tahu Tentang Tubuhmu. Bukune. Jakarta Selatan.

Sari, Teny Tjitra. 2018. Immune Thrombocytopenic Purpura. Sari Pediatri. 20(1): 58-64

Unlu, B. 2018. Effect of blood cell subtypes lysis on routine biochemical test. Journal of Medical Biochemistry. 37(1): $67-76$ 